Tattva, Vol. 3, No. 1, January - June 2011, pp. 57-68

ISSN 0975-332X | https://doi.org/10.12726/tjp.5.4

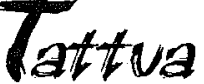

JOURNAL OF PHILOSOPHY

\title{
CONTEMPORARY SCIENCES OFFER INSIGHTS FOR A 'COSMO-THEANDRIC' MYSTICISM
}

\author{
Thomas Manikkam, Ph.D
}

\section{Contemporary Scientific Cosmology- "The Expanding Universe"}

According to the scientific observations of astronomer Edwin Hubble (1889-1953) with the concurred support of Albert Einstein, Stephen Hawking and many others, this universe is a "continuously expanding multi-billion galaxy system." In the light of this scientific cosmology of the "Expanding Universe" the contemporary theologians interpret this fantastic expanse of the universe as set in motion by a "designer" God who governs it with immanently interacting laws of rhythmic motions, and as such this universe indicate intrinsic values for all subsystems including our planet Earth together with all its living and non-living components. Just as every part of the human body is important so also every part of the universe is important for its smooth functioning as set by God's all comprehensive and all enveloping presence in every cosmic unit. Each part inherits an organic value from the value of the whole system of the universe. So observes ecologist Freya Mathews:

Our world is an expression of a selfhood, of a cosmic will-to-exist, and as such has a meaning, and a value, that would not attach to a purely 


\begin{abstract}
'blind' and contingent world. There is in this sense an element of affirmation and fulfilment in the existence of every physical thing. Even the rocks call forth a certain reverence in the light of their participation in this great act of self-realization on the part of the cosmos.
\end{abstract}

According to ecologist, Arne Naess, even non-human life forms have values in themselves and contribute to the flourishing of the manifold life forms in the universe and on earth. Natural entities are to be respected for their own sake instead of regarding them only as means to achieve our individualistic goals. We lose friends when we use them as means for our selfish interest; we lose the pristine quality of nature by regarding if only as a means for our own personal utility. Naess is happy to give Nature its due role and respect. He assigns an ontological status to tertiary qualities in things. He feels that if all the qualities are projections of the human subject then we would get "the thing in itself" about which nothing is known, may be interesting but not informative. Hence what St. Paul wrote to the Corinthian Community-"All things are related to you and meant for you, while you are related and meant for Christ, and Christ is related to God, His Father, and God will be all in all (I Cor. 15:28). This is the holistic picture of relationship and interrelationship of the whole universe to humankind and finally to God. This vision should inspire us to love and respect all creation in their respective roles in the "Harmony of God's Hymn of the Universe," to borrow a phrase from the beautiful book of Teilhard de Chardin - The Hymn of the Universe.

\title{
2. The Scientific Bases for a Holistic Vision of the Universe, Planet Earth and Human Mind
}

Quantum physics rewrote the classical physics' conception of a static, fixed container like universe with ultimately separable constituents. According to the obsenved findings of biological and ecological world views emerging from Quantum physics, the universe is no longer seen as a machine, made up of a multitude of objects, but has to be viewed as one indivisible, dynamic whole whose parts are essentially interrelated and can be understood only as patterns of a cosmic process.

The universe as whole including our planet earth generalized under the common term "The Nature" is a dynamic web of relations with its own overall self-consistency that compels us to recognize that, our human consciousness is, after all, an essential aspect of the universe. According to $G$. Bateson, the author of Mind and Nature:

I Freya Mathews, The Dancing of Wu Li Masters: An Overview of the New Physics, New York: Bantam Books, 1980, 281. 
A Necessary Unity (1988), our mental process is always a sequence of interactions between the various elements of reflection and awareness, what is generally called as 'Human Consciousness'. The explanation of our mental phenomena must always reside in the organization and interaction of multiple parts. The mental function is immanent in the interaction of parts, and the "wholes" are constituted by such combined interaction of differentiated parts. ${ }^{2}$

Life and mind are inbuilt in the dynamics of the self-organization of this universe. Human individual minds are only subsystems of larger manifestations of Mind at the cosmic level. There are levels of mind corresponding to the stages of cosmic evolution. When the mind-matter dichotomy lingers on, it is difficult to see the world as having any mental wave to qualify it as 'mindful'. But in the stratified order of Nature, individual human minds are embedded in the larger Mind of the Cosmos, and these are integrated into the planetary mental system which in turn must participate in some kind of Universal or Cosmic Mind. ${ }^{3}$

Fritjof Capra, an eminent ecologist and author of some bestsellers - The Turning Point ${ }^{4}$, The Tao of Physics etc., sees no hitch in associating this Cosmic Mind with the traditional idea of God. He reflects that God is 'the mind of the universe'.5 Erich Jantisch, the author the controversial book, The Self-Organizing Universe (1980) has a very significant observation to make: "The God-idea does not stand above or outside of the evolution of the cosmos as an ethical norm, but it is placed in true mysticism unfolding into a self-realization of evolution." 6

Erich Jantisch in his more spiritually conceived book - Origins of the Sacred: The Ecstasies of Love and War (1993) makes a very pertinent observation that the scientific world is, at last, coming to see the intuition of the ancients. He observes that when a physicist says that matter doesn't exist, and is really just a mistaken epiphany of the energy-gods, he has almost come full circle, very close to the primitive animist who knows that everything is alive, and derives its liveliness from the winds of pneuma that blows through it.

For George Wald the physical and psychical are complementary aspects of the same reality. His views are serious and thought provoking:

2 G. Bateson, Mind and Nature: A Necessary Unity, New York: Bantam Books, 1988.99.

3 G. Bateson, Mind and Nature, 100.

$4 \quad$ Fritjol Capra, The Turning Point, New York: Bantam Books, 1982,317.

5 Fritjof Capra, The Tao of Physics: An Exploration of the Parallels between Modern Physics and Eastern Mysticism, London: Fontana Paperbacks, 1985, 11.

6 Erich Jantisch, The Self-Organizing Universe, Oxford: Pergamen Press, 1980, 308. 
If I say the stuff of the world is mind-stuff that has a metaphysical ring. But if I say that ultimate reality is expressed in the solutions of the equations of quantum mechanics, quantum electro-dynamics, and quantum field theory - that sounds like good, modern physics. Yet what are these equations? -indeed, what is mathematics, but mind-stuff? Virtually the ultimate is mind-stuff and for that reason deeply mysterious; $[\ldots]$ the universe of space and time and elementary particles and energies, is then an avatara, the materialization of primal mind.?

The new physics seems to chart a new course entering the domain of mysticism. Appreciating the Indian Unitary Vision of Reality, Michael Talbot, a scientist turned spiritual writer says, that matter is a condensed energy form of Consciousness (chit) itself. As it is written in Mundaka Upanishad, by Energy, Consciousness of God or the unbroken Ultimate Reality is meant; from that One is born life, mind and the worlds."

Further, the cosmic law of unity and interconnectedness is echoed in the words of Richard Dawkins, the author of The Blind Watchmaker (1986):

Natural Selection, the blind, unconscious, automatic process which Danwin discovered, and which we now know is the explanation for the existence and apparently purposeful form of all life has no purpose in mind. It has no mind... It does not plan for the future... It has no vision... If it can be said to play the role of a watchmaker in nature, it the blind watchmaker.?

Steven Weinberg, another great physicist, strikes a similar chord, when he says,

We like to think that we are very special and that we are not the result of a series of accidents reaching back to the "big bang" but on the contrary we were within the cosmic plan. We don't realize that this homely earth is a tiny part in a really hostile universe and is destined to perish in extreme cold or heat. "The more the universe seems comprehensible, the more it also seems pointless. ${ }^{10}$

George Wald, "Life and Mind in the Universe," Paper presented in the Seminar of NCERT, New Delhi, February 1987.

8 Michael Talbot, "Mysticism and New Physics," cited by Jitatmananda in Complete Works of Sri Aurobindo, Vol 2, Pondicherry: Sri Aurobindo Ashram, 1993, 65.

9 Richard Dawkins, The Blind Watchmaker, Essex: Lingman Scientific and Technical, 1986, 5.

10 S. Weinberg, The First Three Minutes: A Modern View of the Origin of the Universe, London: Harper Collins, 1993,149. 
There are also critics like Riedel questioning the theories of chance- mutations. Can chance explain everything? Can an orderly universe be the result of mere chance mutations? In fact chance and necessity drive forward the evolution of organisms. Prospects of improvement lie in the realm of accidents, but its success, by necessity, depends on how well an organism adapts to a new situation and a new set up of alignments. When something is selected as normative from the realm of possibilities it enters the realm of necessity. Restricting the number of accidents will increase the prospect that a law of life is being successfully invented during the evolutionary process, restriction of accidents leads to a channelization of possibilities and to subsequent fixation. According to David Bohm, chance and necessary causal interconnections are two sides of every natural process. Neither causal laws nor laws of chance can be basic and final, rather they are approximations. $\mathrm{He}$ says:

Just as a causal law can arise as a statistical approximation to the average behaviour of a large aggregate of elements undergoing random fluctuations, a law of chance can arise as a statistical approximation to the effects of a large number of causal factors undergoing essentially independent motions."

\section{The Universe is a "Divine Milieu"}

Some of the foundational concepts we have about God as revealed to us from the Biblical sources are that God is One Omnipresent, All Conscious of everything that happens in the universe, almighty, all good, all true, all beautiful, all loving, all merciful, all compassionate, all forgiving, and all just. These are the transcendental qualities attributed in the super-eminent degree to the Ultimate Reality. Almost all human conceptions recorded in the religious annals of the various civilizations, cultures, literatures and scriptures, describe the essential characteristics of the Ultimate Causal Principle behind this universe in these terms of qualities, and this Ultimate Reality had been honored by certain appellations such as Yahweh, Allah, Alaha, Brahman, Isa, Tao, Lord, God, etc. The African Traditional Religions (ATR) too have most of the above mentioned transcendental qualities attributed to Unkulunkulu "Lord of the Universe." The sages, mystics and even common people of the ancient India, from time immemorial, visualized that this "moving universe is primarily indwelt by the Lord," and hence this universe is a Divine Milieu, as intuited by the sage of the Isavasya Upanishad who rhymed:

" David Bohm, Causality and Chance in Modern Physics, London: Routledge \& Kegan Paul, 1959,745 . 
"Isâvâsyam idam sarvam, yat kincha jagatyâm jagat, tena tyagtena bhuniidha, ma gridha kasyaswidhanam" (Isa Upanishad 1). ("This moving world together with all its minute particles is indwelt by the Lord; renouncing it, enjoy it; don't possess the wealth that belongs to somebody else.")

God's immanent presence in this universe makes the whole universe a Sacred Sanctuary, a "Divine Milieu." Since this universe is primarily His Home, His indwelling habitat, we as His creatures are His "guests," invited to share His own home and his fellowship and hospitality. His invitation for us to share His fellowship, from the moment of our bitth into this world, also includes a sharing of His fellowship with all other beings in His household. We are privileged to share His life with all other fellow beings. Every being / creature in the Household of God has a holistic placement in His immanent Wholeness. We cannot close our eyes pretending not having seen it, or understood it. That is why the Paleontologist turned theologian Teilhard de Chardin described this world as a Divine Milieu.

Our earth, and all that are in it, is not an empty space, nor is it a "no-man's land." As Raimond Panikkar has rightly argued in his book the Cosmo-theandric Experience (Orbis-1993) there cannot be a "no-man's land in the Land of Being" who is One and all pervading. The truth is that all that exist had been long - long ago occupied by the Lord of the universe from its foundation, and "His Almighty Power and Divinity are clearly manifested in the Creation of this Universe" as St. Paul wrote in his letter to the Romans (Rom. 1:20). From the foundation of this planet, this earth so far explored by our scientists as the only life-sustaining planet had been the house of the "Living God". He is the all enveloping, pervading as well as indwelling "Parent-Principle," generating all life-forms and guiding their ongoing mutation and evolution in their progressive order of species generation, as to survive interdependently, as well as inter-relationally, i.e., holistically. He is constantly giving life and energy to every new "seedling" or "sibling" born into this world, both as its paternal and maternal generative source of life, fertilizing and begetting it into a family of numerous fellow living beings with a right to live and fulfill a set goal of its "being in this world." When a new life is born into this family of living beings, all existing living beings are supposed to welcome the new-comer warmly into their family and "accommodate" it giving its due place in the network of the web of life in the lap of Mother Earth, and Panikkar rightly observes: It is in the birth of a new life that the Heaven and Earth embrace in a communion of love.

\section{The Cosmotheandric Vision of the Unity of Reality}

The "Cosmo-theandric" vision of unity of reality and harmony of God-experience by humans in the universe is a corollary of the reality of the immanent presence of 
God in the Universe and in the human persons. Although in the western mechanistic world view our universe is generally qualified as a vast space in a process of expansion, meant for the humans to explore, occupy, sperate and control, in the Biblical revelation as well as in the ancient world-visions of our forefathers, this universe is a visvam, a manifestation of God's presence, and further, as Bhagavad Gita says, it is the 'Form of God' - visvarupam (Gita 11 :6). In such a unified and holistic vision of the universe, our human life is also understood as a living participation in the life of the Divine in close affinity with the Universe, the living environment of mankind and other fellow beings. This is in essence the Cosmotheandric experience as described by Raimond Panikkar about the unity of Reality - a three dimensional co-existence of the wholeness of One Being in the modes of cosmos-theos-andronos i.e. cosmo-theandric harmony of the wholeness of one Reality in three co-relational modes of existence. Since all life emerge from one source of life, that is the Divine Creative Power, we have to relate ourselves to this divine source (theos/thea-divinity) and the cosmos (universe) in a harmonious communion of a holistic inter-subjectivity without having any conceptual conflict in our understanding of the unity of the Creator and $\mathrm{His}$ Creation, the universe and the humans. In Panikkar's own words the Cosmo-thea-ndric unity is articulated as follows:

It is neither a merely diving affair, nor a purely human endeavor, nor a blind cosmic process, it is human, divine, and cosmic, all in one... It is cosmic-theandric. God, man and the universe are correlates. God without man is nothing, literally "no-thing". Man without God is exclusively a "thing," not a person, not a real human being, while the world, the cosmos, without man and God is "anything", without consistency and meaning, it is sheer unexisting chaos. The three are constitutively connected. ${ }^{12}$

The Cosmo-thea-andric vision (Universe-God-Humankind Configuration) of the unity of Reality is further highlighted by Scriptural testimonies about the enveloping and indwelling presence of the "Spirit of God hovering over the waters" (Gen. 1:2), and the same Spirit as Sophia (Wisdom) empowered every creature being the dynamic force of everything (Wisdom 7:28-8:1 ff), and the same Spirit according to St. Paul indwells in the heart of every human being (Rom.8:9-11;14-16), empowering us to pray to God, calling God Abba - Father.

12 Raimundo Panikkar, The Vedic Experience: Mantramanjari, Delhi: Motilal Banarsidass, 1994, 73. 
The same Spirit of God claims to have entered into the heart of everything Sarvasya châhamhrdi sannivishti. "And I have inserted myself into the heart of everything" (Bhagavadgita 15:15) one of the classical spiritual synthesis of the Vedic and Upanishadic traditions of the ancient seers of India, and this insight is very experiential and highly motivational even for people of contemporary India, may be, the same is very inspiring for all spiritually oriented people all over the world. The divine person Krishna, the Spiritual preceptor of Bhagavadgita, identifying himself as the all pervading Divine Spirit, motivates Arjuna, his disciple, to boost up his dwindled spirit and empower himself to do his duty of fighting for righteousness (dharma). He was given the insight to feel that the almighty God himself is dwelling within him energizing him. God is said to have not only an overall command over the whole universe, but He has entered into the heart of everything, energizing and enlivening everything from within.

\section{Cosmotheandric Experience as a Mystical Contemplation on the Harmony of God}

The Cosmotheandric experience described above is also our contemporary Christian spiritual experience in our life in an "expanding universe," and our mystic experience of its harmony is a spirituality of a lifelong integrating process of our relationship with God in His creation, which is groaning for its progressive unification with the "Omega point" of the whole universe which is ever expanding and growing into greater perfection and unification. ${ }^{13}$ It consists in the ongoing process of seeking after the wholeness of the truth of this "Divine Milieu" and getting enlightened of it at all the times while we contemplate on its progressive revelation of the truth of this Universe, the "Divine habitat" of our life and that of our fellow beings. This contemplation on the inner mysteries of the universe would motivate us to collaborate with every being in this universe for improving their lot in this process of the liberation of the universe from its decaying deterioration. St. Paul describes this liberation process of the Creation through the collaboration of the 'Sons of God' as follows:

All of creation waits with eager longing for God to reveal his sons. For Creation was condemned to lose its purpose, not of its own will, but because God willed it to be so. Yet there was the hope that creation itself would one day be set free from its slavery to decay and would share the glorious freedom of the children of God. For we know that up to the present time all of creation groans with pain, like the pain of childbirth.

13 Raimundo Panikkar, Cosmotheandric Experience-emerging religious consciousness, New York, Orbis Books, Maryknoll, 1993. 
But it is not just creation alone which groans; we who have the Spirit as the first of God's gifts also groan within ourselves, as we wait for God to make us his children and set our whole being free (Rom.8: 19-23).

Our Cosmotheandric mystical experience of the Divine Harmony in the Universe is also related and open to a Holistic Eco-spirituality which is the spirituality of experiencing "wholeness" and "perfection" of our life lived in interdependence and interrelationship with the whole Creation, while enjoying the "Joy of the Holy Spirit" who is operative in the heart of the universe, in the heart of every human being, who simultaneously envelops and indwells this cosmic habitat while making it a Temple of the Divine, a true Divine Milieu. This vision has its miniature in our own bodies, as St. Paul writes in his first letter to the Corinthians: "Don't you know that your body is the temple of the Holy Spirit, who lives in you and who was given to you by God"(I Cor. 6: 19).

\section{Practical Applications of the Cosmotheandric Mystical Experience}

The Cosmotheandric vision of the unity of the whole Creation in the One Designer God is also well interpreted by Ecosophy and Quantum Physics, two of the most advancing philosophical and scientific interpretations of our times. Both as allied branches of cosmological sciences have discovered today numerous links of harmony of relationship of humankind to Nature, the living habitat of all beings, while being herself remaining a Temple of God. These sciences have also discovered existential and intentionality-relationship of humankind with Nature, and together with her our common interrelationship with God, our common creator. There is an explosion of the spiritual possibilities opening up for humankind to aspire and activate in the future, respecting Nature and serving her like our mother; for in her is manifested the "Almighty Power and Divinity of God from the foundation of this world" (Rom $1: 20$ ) and the human consciousness is always awakened from its dormancy by every contact we make with our living habitat, the lap of our Mother Earth. Hence we need a twofold spiritual awakening today:

a) Be honest and responsive to God's Designs in the Nature, because the divine force in Nature is the full time active "Almighty Power" permeating the entire universe to activate it making it capable of producing everything that is needed for the sustenance of all creatures. The humankind has no right to arrogate to itself all the potentialities of this mysteriously evolving universe denying its motherly availability to all other creatures. Exploitation, domination, destruction and devastation of the resources of our "Planetary Common Wealth" are to 
be considered as expressions of arrogant selfishness, self-centeredness and crass negligence over the simple existential rights of all other beings however insignificant they are.

b) Be ready to respect the whole universe, as the house of the living God and our own planet as our own "Sweet Home" because we are invited by God the host of this house to be born into the lap of this Mother Earth which is just one of the fragile homes, which God created as the nurturing and nursing Mother. This Planet Earth nourishes us with all her wonderful life sustaining nutrients for our progressive growth into maturation and perfection as long as we are allowed to be here in this playful countyard. We are brought to this temporary earthly home of the expanding universe to live here for a short while as playing children in the courtyard of the House of God. As invited guests to the House of God we are not supposed to do anything that is damaging to its sustainability and viability, rather we are obliged to keep this house in improved conditions reset for the next generation of the "Children of God" who are awaiting entry into the motherly bosom of our existential cradle of the "Cosmic Expanse." Our short "life is a transit from the womb to the tomb of our Mother Earth," through the mediation of our own beloved mothers; hence respectfully deal with our common Mother Earth just like we respect and honor our own biological mothers!

Cosmotheandric Mysticism, therefore, is based on some of the axioms of Nature's behavior keenly observed by the contemplatives of all times. Such meditative observations on the universe inspired the great masterminds of ancient times as well as of our own times, and they proposed to us to apply some of the basic laws of Nature in the manufacturing of herbal medicines, which are naturally preventive and curative means of holistic treatment of most of the illnesses caused by our estranged relationship with Nature and Natural elements which are supporters of life, such as air, water, moisture, light, and fire. These basic elements of Nature above all favour us to enjoy a peaceful life in harmony with Nature and its various forms of living and non-living beings. Some of the foundational rules of conduct that we should understand and observe in dealing respectfully with the Nature and her productivity and progress are expressed in the form of axioms, such as understanding the "Unity of Nature," "Interdependence of Nature and Atmosphere," "Co-relation of Elements," "Regularity of Species-generation, "Convertibility of energies," "Mutation of Geo-biospheres," etc. 


\title{
6. Virtues to be practiced for our Harmonious Life on Earth
}

\author{
(i) Grow beyond the 'Culture of Violence' towards Nature, \\ Humanity and God
}

Practicing non-violence (ahimsa) to Nature and natural realities is very basic to cosmo-theandric spirituality. This is also the inspiration behind the well-known three levels of transcending the culture of violence, namely, manasa-vaca-karmanai.e. mental non-violence, verbal non-violence and non-violence in deed. Positively conceived and explained these are to be practiced on three levels of our human consciousness and behavour.

Firstly, mental non-violence is practiced by thinking positive about life and its variety of situations interacted with our living environment, and maintaining a 'feel good' attitude towards the opposite challenges of the various situations of Nature, and deciding in favour of taking 'face the challenge attitude' towards the opposite sifuations and never taking an escapist or 'damn it' attitude. Eventually this positive mental disposition will tone us up to be more tender, serene, compassionate, kind, gentle, friendly as well as to be 'attractive and affectionate' towards others with some extra charm and humor.

This mental peace-oriented thinking is what is underlying our common expressions of console, like, "Take it easy," "Never mind," "Forget it," etc., and these often do a great psychological service-stroke to our wounded feelings and depressed state of personality. Sri Buddha, Sri Krishna and Jesus Christ, Francis Assisi, Mahatma Gandhi and many other great personalities this patient Mother Earth generated in the past are heroic examples of this great multi-faceted virtue called "non-violence": non-violence first towards ourselves, then towards our living environment consisting of the "lilies of the field," the "sparrows of the air," "the doves of the fields," "the snake peeping out of its hiding hole," the honey bees of our gardens, the dolphins of our oceans, the ant-lines of our roadways, the anthills of our lands, and all such curious creatures of God's Creative Word. They are all there as wonderful creatures of our Nature, teaching us inspiring lessons of being 'innocent,' 'simple, 'humble,' 'wise,' 'loving,' 'co-operative', 'kind,' 'endearing,' 'charming,' 'self-reliant' and hard working, and yet depending on Somebody Who provides for them all day and night. Why should we think of doing violence to their habitats? Let us think of a policy of "live and let live" and never destroy anything that God has set in motion to play the dance of Nature in the wider Cosmic Expanse. 
Secondly, verbal non-violence is avoiding angry words, abusive language, condemnatory or cursing expressions in our conversation with others, even when others may be using them against us. Positively described, verbal non-violence is speaking complimentary words about others in view of encouraging them and appreciating their goodness and achievements, not as flattery but as sincere expressions of regards and well wishing. It consists also in soft speaking to other human beings and not shouting at them, even if they are our subordinates, babies or children. Verbal non-violence has to be practiced by observing the niceties of courtesies and etiquettes in social interactions. Non-violence in words also implies to engage in edifying discourses and never enter into quarrelsome arguments with our fellow humans. Such heated arguments generate disturbing waves of "sound pollution" in our living environments, domestic as well as working places disturbing the mental peace of all others. Angry words of superiors and higher officers generate 'fear complexes,' "phobias' and hatred in the minds of the subordinates and these destroy spontaneity, creativity and enthusiasm for doing their prescribed duties.

Thirdly, non-violence in deeds is avoiding all forms of violent actions, such as physical attacks, blows, beating, hitting, shooting, looting, raping, murder etc. Positively described, whatever we do to promote good relationships between persons, environments, families, communities and assemblies as well as maintaining "law and order" in chaotic situations, are all deeds which promote peace and harmony in the Nature and in the Society of human transactions and interactions.

Our practice of ahimsa is not to be compromised with the western materialistic ideology of exploitation of Nature under the pretext of "progress and development." The western industrialists, who have de-sacralized and irreparably polluted their own countries' geographical areas of this planet, have recently started polluting the natural environments of the developing countries' water ways, forests and their plain lands by dumping toxic wastes like atomic reactor's waste loads, chemical and other industrial discharges from their factories. This is institutionalized sins against humanity under the pretext of global development and global marketing. The right word for this kind of atrocities of the industrial giants is 'exploitation' of the patience of the larger populations the developing nations and "gross violation of the patience" of Mother Earth. They are also insensitive to the human rights of the peoples of the developing countries.

Already some of the world class manufacturing giants like Coco-Cola and Pepsi Cola have exploited, spoiled and polluted the water resources and the living environments of millions people of the developing countries, endangering their sane and safety means of healthy life-all under the tantalizing banner with the confusing slogan of "industry for progress"! Is consumerist industry alone to be 
considered progressive? If it is so, then we are blindly led to the tragedy of a catastrophe of suffering from the "Poverty of the Spirit".

To prevent this catastrophe we need challenge these industrial giants and their behaviour in the court of Law as the people of the village of Plachimada, in north Kerala, India, have done recently. These people could legally stop the Coco-Cola giant from continuing polluting the drinking water wells of the local people by means of proper court orders. They have shown effectively the values for good living and right ways of sustainable development, in tune with the "values of sanity and sanctity" as well as values of "sparing and sharing," in the true spirit of "non-violence in deed" towards Nature, our motherly habitat, as well as to our own homes and their neat and tidy environments.

\section{(ii) Practice the Spirituality of Renunciation and Sharing}

From the vision of this world as God's dwelling place both in and out, there emerges a spirituality of balanced enjoyment of the goods of this world, and not an exploiting consumerism at the expense of the less privileged. The instruction, tyagtena bhunjeedha (enjoy (this world) while being ready to renounce the excess) is a wise exhortation given by the sage of Isavasya Upanishad quoted above. It is a spiritual maxim as well as an ethical norm of using this world, and it derived logically from our vision of the world as a "Divine Milieu." It is God's world offered to us to enjoy moderately sharing with all its inhabitants. Since this world belongs to God, and we are all His invited guests to His home, we humans have to see that we share the blessings of the House of God always with a spirit of renunciation of something for the benefit of our fellow beings. This renunciation is not a negative attitude to the goods of this world but a positive decision to share the goods with a community sensitivity. Because as guests we are all equals before the host who brought us all to this "House of His Being" sharing his Beingness with all his creatures.

It is interesting to note here, that this instruction of the Isavasya Upanishad was first imparted to the students of ancient schools which were the houses of great masters (Gurukulas), where all students irrespective of their family ancestry or caste differentiation were instructed to treat each other with equal respect and share everything of the Gurukula with a sharing and sparing fraternal concern. This was the ideal of good egalitarian education backed up by a concern of fraternity lived and experienced in the Gurukulas of ancient India, where the invisible Real Guru was the Lord of the Universe, who was represented by the person of the teaching Guru of the Gurukula. 
Just like there developed a Spirituality of renunciation and sharing on the basis of the Eco-theology explained above as is evident from the Isavasya Upanishad and Bhagavad Gita, there is also derived an Ethics of Non-possessiveness and nonaggressiveness. A good eco-theology generally highlights a good morality and an ethics for practical life in harmonious relationship with the entire creation. This is so because the interrelationship between theory (theorea) and practice (application of the vision in life) has been considered to be flowing logically and spontaneously making the theory as the fountain of the practice. Faith and morals had been understood as so integrally connected from the beginning of human culture. Hence we have the foundation of a non-possessive and non-aggressive ethics. Transact the wealth of the house of God without having any possessive attitude over it. Because the whole world all that is in it belong to the Lord of the universe. Hence ma gridha kasyaswiddhanam - don't arrogate or possess the wealth that belongs to somebody else. We are only allowed to use it in as much as we need it and not to possess it as to feed our greed on it. It is an "ethics of need" and not an "ethics of greed" that is propounded in the Upanishads in general, especially in Isavasya Upanishad. Thus a good Eco-theology paves way for a balanced economic transactional system based on the needs of everybody and not controlled by the greed of somebody.

\section{To be Kind towards our own "Mother House" this Planet Earth}

Imaging earth as mother can be helpful to stop our conflict with nature and to nurture an ecological worldview. The capacity to generate and nurture all forms of life makes earth eminently feminine. But today for some people earth is material and not yet maternal. The earlier mother-offspring relation turned into one of resource-exploiter; respect and veneration gave way to greed and the urge to conquer and possess. It is ironical to view humankind, the one-time offspring of Mother Earth now aggressively trying to be the lord of the same Mother!! This attitude has resulted in the rape and pillage of the earth and her degradation to be waste land, as if she is a "No-Man's Land". But it must be an all time truth that in the "Land of God, there is no 'No-man's land".

Therefore, in the wake of the ecological crisis today, it will be good for us to retrieve our lost consciousness about this universe. This expanding universe is a fully Godoccupied space that is enveloping us around. It is in "His Holy, Mysterious and Silent Presence" which is always "expanding" not under the controlling power of 
any human agency. We are privileged to gaze and even telescope into this wonderful Cosmic Expanse of more than two billion galaxies (recent pictures taken by Hubble's Telescope) and enjoy its grandeur and magnitude and be taken up again and again by the great "Wonder" our ancient visionaries were having. This is an aspect of the Cosmotheandric Mystical vision of the Universe which any human being of good fantasy can visualize and contemplate to experience the glory of God shown up there in the Expanding Universe as well as enjoying the smiling face of our own Planet Earth in every turn of her Seasons, and this must be our true "Cosmotheandric Experience."

\section{Respect the Feminine Characters of Planet Earth as Generating Shakti or Motherly Gaia}

Feminization of Nature implies the idea of Shakti or creative energy and its inherent power of synergy according to Indian mythological and aesthetic traditions. The same feature had been visualized by the ancient Greek cosmic mythologies under the symbol of Gaia. The concept of Sakti, as the primordial creative power, is the feminine potency of mother earth. This has been variously described in some of the Indian Puranas like Devi-Mahatmyam, and philosophically interpreted in the Vedantic school of Saiva Sidhanta. Behind the nature- personification is the insight into the law of nature as the force of ita that sustains the world. It provides humans with a sound norm for environmental ethics. Human culture must be integral with the laws of nature. Feminization of nature also shows the feminine dimension of reality, a dimension, the patriarchal culture of some dominant civilization had lost long ago. Recovery of this dimension can enrich our lives. It will imply the appreciation of the feminine dimension of reality in all its different realms: divine, human and natural. In order to recover the feminine principle of the Divine Harmony active in the progressive evolution of the expanding universe we have to perceive Nature as alive represented by our motherly women as co-creatrix with the divine Shakti bringing forth new babies into the house of the Divine Shakti, who is equally describable as motherly Gaia encompassing and indwelling the whole universe rather than remaining as a transcendental supervisor far away from the accessibility of the Creation.

Maternity of Nature is not just a mythological or cultural symbol but a scientific truth. A tree cares for the seed with great precaution surrounding the embryo with layers of protective substances and storing around it the first nutrients it needs when a seed breaks out of its shell as a living sapling. In the lower levels of nature motherhood exists in humble forms. In the mammalian stage there is a strict bond of communion between the mother and child. The universe itself appears to have a 
feminine dimension. For, in the so-called barrenness or emptiness of atmosphere there are the microscopic seeds of the phyktoplantans which germinate in the steady waters or pools making the whole base green; and these little micro-plants cluster to form algae, hair like net work of water lilies which form a web of interrelated organic life-system which becomes the breeding ground for many other fungus kinds. The profound mysteries of life are handed down to us through symbols; and symbols give rise to thoughts. The mother symbol engenders in us visions of harmony and peace, and it also evokes respect. Our human task is to respond appropriately to the feminine dimension of Nature which is another dimension of the Cosmotheandric Mysticism.

\section{Shift from Anthropocentrism to Cosmotheandric Holism}

We have to develop our consciousness more and more eco-friendly, a consciousness which will involve a transition from anthropocentrism to eco-centrism, an awareness of our rootedness in the womb of mother earth much more than our dominating 'headship' over her. Our consciousness of our situatedness in the bosom of Mother Earth must be that of an infant, as we were all once infants playing in the lap of our own mothers, were sucklings of the breasts of our mothers, so are we all doing even as we have become adults, sucking the life-giving and nourishing "nectar of Mother Earth," drilling deep into the under-earth storage reservoirs. So we owe much to our Mother Earth and we have to acknowledge this life-indebtedness to her in all humility, respect and honour, for nurturing us like a foster mother once we are out of our own mothers' womb. Our life journey, then, is to be understood as a holy pilgrimage from the womb to the tomb of Mother Earth.

Hence, let us not be so cruel to poison, contaminate or adulterate this nectar of life, filtered through the numerous porous silt strata of our Mother Earth. The Earth stores the rain water filtered through her silts in her interior rocky cellars, as if in reservoirs well protected from contaminating elements from outside. This is the precious drink we drill out from the womb of Mother Earth, this becomes our new umbilical cord, our life-line connected to this Earth for our survival as long as we are here in her lap. Water is the most energizing life-sap of all living beings. We should not forget the simple biological fact and truth about ourselves, humans, that about $90 \%$ of our own body is filled with water and our whole body functions like a sponge soaked in water which lubricates every tissue of our body, making it alive and continuously refreshing it round the clock. So the water we drink should be pure, safe and uncontaminated with toxic elements from the land surface or from the atmosphere during rainy season. Our drinking water should not be a 
carrier of disease causing bacteria. This is one of the important warnings of the cosmo theandric vision of Nature to which our life is holistically connected for its survival. This is what is meant here by suggesting to our own options to have a decisive shift from our "anthropocentric adventures on Earth" to a more cosmotheandric participation in the maintenance of our Mother Earth, by means of our services towards the preservation and replenishment of the life-supporting resources of our Planet Earth, the only life-sustaining habitat in the entire Universe explored so far, which should be scrupulously maintained as a safe home for numerous little infants of our own successive generations who are on the waiting line to be born into this temporal milieu of "The Eternal Divine."

\section{Conclusion: Make this World a 'Sweet Home' for all beings}

Most religious traditions sometime exhibit an ascetic undercurrent for self-purification, and when it is overemphasized it goes to the extent of denial or disparagement of the world. It is presupposed that the self and the world are essentially separate and that the one can be heeded ignoring the other. Dubbed as a maya or a shadowy realm, the world turned out to be a transit point and ceased to be a real home. It is considered as a battlefield where the forces of good and evil face each other. In this battle any kind of domination can be misinterpreted as God's will because each one thinks that he is on God's side battling the evil. Then the world is just a background, a proving ground for humans who only matter. The world was also understood as a trap wherein we may get caught up and enslaved. To affirm a transcendental reality in the material realm was looked upon with contempt by negativist spiritual visionaries. But the sense of detachment from the world do not achieve often the intended sense of detachment from the ego or selfishness of ambitious people. Trying to escape from something that we are dependant on, breeds a love-hate relationship with it. This love-hate relationship with Nature is permeated in our present day consumerist culture, and it inflames a twofold desire: to destroy or possess, crave for or avert from, and this is a conflict inflaming us in a kind of vicious circle of confusion, and yet in our new eco-friendly and "cosmotheandric" attitude to the Universe we have to resolve it with prophetic vision and wisdom.

Hence we have to consolidate all our available wisdom today in order to make this planet (griham) a "sweet home" for all beings, living and non-living, to live in fellowship and familial partnership, and never get tempted to turn it into a battlefield of aggression, exploitation and possession, nor a prison of locked relationship; but a real household of free-beings, having rights to exist, live and flourish in a God- 
set environment of freedom, a freedom not to be suppressed by the ego-centric aggressiveness of a few humans, but preserved by all humans with a good sense of stewardship, which God seems to have set in the heart of mankind as the primary precept (Genesis 2:15) of the primal partnership of humans in the "Garden of Eden" which God appreciated as "good", "very good" (Genesis 1:31).Let us also practice the great virtue of generosity (udarata) which is the characteristic virtue of those who make this world a home (kudumbam) for all beings to live in the freedom of the family of God's creation, remembering the wisdom of our great teachers who defined a home as udaracharitanam tu vasudhaiva kudumbakam, "a home, indeed, is the good earth of generous people" (Hitopadesha 1:70).

This must be a guideline for living the new cosmo-theandric vision of human life in close co-existential relationship with all other fellow beings in the lap of Mother Earth, our "Sweet Home" on this shore of the flow of time, where we have to strive to grow in loving all beings as "to become perfect as the Heavenly Father is Perfect" (Mt.5:48). This is possible when we expand our love relationship with all beings beyond our private intimacies and personal hatreds, swimming over to the "Further Shore," into the Expanse of God's Holy Presence of timeless Immensity and Mystery, glimpses of which can be only experienced by us if we can open our mystical eyes to see the wonders of this Expanding Universe which is equally extensive to the overwhelming Presence the God who is beyond all astronomical boundaries, as $\mathrm{He}$ is Mysteriously and Silently so close to us all that the truth is that "It is in Him we live, we move and have our being" (Acts. 17:28).

\section{References}

For advanced reading on the theme of this paper, I would recommend the following books:

01 Darmuid O'Murchu, Quantum Theology- Spiritual Implications of the New Physics, New York, A Crossroad Book, Crossroad Publishing Company, 2004.

02. Henry A. Garon, The Cosmic Mysticque, New York, Orbis Books, 2006.

03. Judy Cannato, Radical Amazement (Contemplative Lessons, from Black Holes Supernovas, and Other Wonders of the Universe), Notre Dame, Indiana, Sorin Books, 2006.

04. Christoph Cardinal Schoenborn, Chance Or Purpose, (Creation, Evolution, and A Rational Faith), San Francisco, Ignatius Press, 2007.

05. George V.Coyne s.j. and Alessandro Omizzolo, Way Farers in the Cosmos (The Human Quest for Meaning), New York, Crossroad Book, 2002.

06. Harold Wells, The Christic Center (Life-Giving and Liberating), New York, Orbis Books, 2004.

07. Ilia Delio, Christ in Evolution, New York, Orbis Books, 2008. 